\title{
Effects of Oil Pollution on Coral Reef Communities
}

\author{
Y. Loya and B. Rinkevich \\ Department of Zoology, The George S. Wise Centre for Life Sciences, Tel-Aviv University, Tel-Aviv, Israel
}

\begin{abstract}
This paper reviews our knowledge of oil-pollution effects on coral-reef communities, concentrating on research done since the last review on this subject by Johannes (1975). The review focusses on crude-oil effects on scleractinian corals and octocorals and summarizes the small amount of work conducted on other reef organisms, as well as on the reef flora. Until 1975 there appeared to be no conclusive evidence that oil floating above the reef damages the corals. Although conflicting reports continue to appear in the literature, growing evidence indicates a detrimental influence of oil pollution on coral-reef communities. Laboratory experiments and long-term field studies in the Red Sea witness detrimental effects of oil pollution on reef corals, such as complete lack of colonization by hermatypic corals in reef areas chronically polluted by oil, decrease in colony viability, damage to the reproductive system of corals (smaller number of breeding colonies, decrease in number of ovaria per polyp, fewer planulae per coral head and premature planulae shedding), lower life expectancy of planulae and abnormal behavioural responses of planulae and corals. Other detrimental effects on reef corals caused by crude oil, mainly reported from the Caribbean, include lower growth rates, direct damage to tissues, thinning of cell layers and disruption of cell structure, damage to tactile stimuli and normal feeding mechanisms, excessive mucus secretion leading to enhanced bacterial growth and eventual coral destruction. All investigators studying effects of crude-oil emulcifiers on reef areas polluted by oil conclude that these enhance the damage; hence mechanical oil removal is recommended. There is urgent need for more field and laboratory research on long-term oil-pollution effects on coral-reef communities. Suggestions are made as to the type of studies required for a better understanding of the problem.
\end{abstract}

\section{INTRODUCTION}

Coral reefs are the most diverse and complex communities in the marine environment. Hermatypic corals play a key role in forming the structure of coral reefs and providing substrate and shelter for a wide variety of organisms. Acute damage to corals may result in a collapse of the complex community of organisms, which live in close association with the corals. Concern for damaging effects of oil pollution on coral-reef communities is currently growing. For example, even before any incidents occurred in the Great Barrier Reef, oil-exploration permits were suspended and two Royal Commissions of inquiry into the effects of oil drilling on these reefs were convened (Horler, 1974).

This paper reviews our present knowledge on oilpollution effects on coral reefs. It concentrates particularly on research done since the last review on this subject by Johannes (1975). Johannes concluded his review by stating that to date there appears to be no conclusive evidence that oil floating a bove reef cor- als damages them'. This conclusion was drawn in view of laboratory reports by Grant (1970), Johannes, Coles and Maragos (unpublished, after Johannes et al., 1972) and field reports (Rützler and Sterrer, 1970; Spooner, 1970; Shinn, 1972). However, since then, evidence has been accumulating which indicates various detrimental effects of oil pollution (especially chronic oil spills) on coral reproduction, growth rate, colonization capacities, feeding and behavioural responses.

Oil-pollution studies will be reviewed in Marine Ecology', Volume $V$ (Kinne, in press). Such studies involve primarily three basic directions: (1) bioassay investigations in which the response of an organism to environmental conditions is measured, (2) determination, at the subcellular level, of the actual morphological or physiological basis for the effects observed, and (3) evaluation at the level of populations and communities of changes in patterns of distribution and abundance of affected organisms (O'Brien and Dixon, 1976). The present review focuses on the effects of oil on scleractinian corals and octocorals. However, it also summarizes the small amount of work conducted on 
Table 1. Reported oil spills near coral reefs

\begin{tabular}{|c|c|c|c|}
\hline $\begin{array}{l}\text { Time, tanker } \\
\text { and site }\end{array}$ & $\begin{array}{l}\text { Amount and type } \\
\text { of oil spilt }\end{array}$ & Reported effects & Reference \\
\hline $\begin{array}{l}\text { Second World War, } \\
\text { unknown, Japtan } \\
\text { Island, Enewetak }\end{array}$ & & $\begin{array}{l}\text { In } 1974 \text { many porous rocks and boulders near the } \\
\text { remains of the ship are still heavily impregnated } \\
\text { with tarry residues from the spill' }\end{array}$ & Johannes (1975) \\
\hline $\begin{array}{l}\text { Second World War, at } \\
\text { least } 28 \text { tankers, Gulf } \\
\text { of Mexico and } \\
\text { Caribbean Sea }\end{array}$ & $\begin{array}{l}\text { Several thousand } \\
\text { tons }\end{array}$ & & $\begin{array}{l}\text { Dennis, 1959; US Coast } \\
\text { Guard }(1959,1968)\end{array}$ \\
\hline $\begin{array}{l}\text { Second World War, } \\
\text { Dry Tortugas }\end{array}$ & & Young mangroves of $4-5$ years were killed & $\begin{array}{l}\text { Odum and Johannes } \\
\text { (1975; pers. comm. of J. } \\
\text { Davids) }\end{array}$ \\
\hline $\begin{array}{l}\text { 1957, 'Tampico } \\
\text { Maru', Baja } \\
\text { California, Mexico }\end{array}$ & 7153 tons & $\begin{array}{l}\text { Many invertebrates and fishes killed. Abundances } \\
\text { of certain species somewhat changed even } 12 \\
\text { years after the wreck }\end{array}$ & Mitchell et al. (1970) \\
\hline $\begin{array}{l}\text { 1962, 'Argea Prima', } \\
\text { Puerto Rico }\end{array}$ & $\begin{array}{l}10,000 \text { tons } \\
\text { (crude) }\end{array}$ & $\begin{array}{l}\text { Death ot adult and juvenile lobsters, crabs, sea } \\
\text { urchins, sea stars, sea cucumbers, gastropods, } \\
\text { octopuses and fishes. Thalassia beds degenerated, } \\
\text { rocky areas denuded of algae. Extensive damage } \\
\text { to the mangrove-swamp habitat }\end{array}$ & Diaz-Piferrer (1962) \\
\hline $\begin{array}{l}\text { 1966, 'British Crown', } \\
\text { Persian Gulf }\end{array}$ & $\begin{array}{l}25,000 \text { tons } \\
\text { (Qater crude) }\end{array}$ & & $\begin{array}{l}\text { Beynon (1971) } \\
\text { Nelson-Smith (1972) }\end{array}$ \\
\hline $\begin{array}{l}\text { 1967. 'R. C. Stoner', } \\
\text { Wake Island, mid- } \\
\text { Pacific Ocean }\end{array}$ & $\begin{array}{l}22,000 \text { tons } \\
\text { (Gasoline, jet fuel, } \\
\text { turbine fuel, Diesel } \\
\text { oil, Bunker C) }\end{array}$ & $\begin{array}{l}\text { About } 2500 \mathrm{~kg} \text { of inshore reef fishes killed and } \\
\text { stranded on shore. Snails and sea urchins found } \\
\text { dead in large numbers. Either gasoline or black oil } \\
\text { thought to be lethal to the fishes }\end{array}$ & Gooding (1971) \\
\hline $\begin{array}{l}\text { 1968, 'Ocean Eagle', } \\
\text { San Juan, Puerto Rico }\end{array}$ & & $\begin{array}{l}\text { Many intertidal organisms killed or damaged by } \\
\text { oil and emulcifier, including fishes, molluscs and } \\
\text { algae; subsequent recovery good }\end{array}$ & Cerame-Vivas (1968) \\
\hline $\begin{array}{l}\text { 1968, General- } \\
\text { Colcotronix } \\
\text { installation } \\
\text { Eleuthera-Bahamas }\end{array}$ & $\begin{array}{l}1 / 4 \text { of its cargo } i, e . \\
4,500 \text { tons, crude }\end{array}$ & $\begin{array}{l}\text { Few details on biological damage caused by spill. } \\
\text { Chitons and crabs unharmed by oil }\end{array}$ & $\begin{array}{l}\text { Spooner \& Spooner } \\
\text { (1968) }\end{array}$ \\
\hline $\begin{array}{l}\text { 1968, 'Witwater', } \\
\text { Galeta Island, Canal } \\
\text { Zone }\end{array}$ & $\begin{array}{l}20,000 \text { barrels Diesel } \\
\text { oil and Bunker C }\end{array}$ & $\begin{array}{l}\text { Harmful effects to meiofauna, mangroves, } \\
\text { reduction of fiddler crab population, elimination of } \\
\text { algae and sedentary animals on mangrove stilt } \\
\text { roots. Reef corals were the least affected }\end{array}$ & $\begin{array}{l}\text { Rützler and Sterrer } \\
(1970)\end{array}$ \\
\hline $\begin{array}{l}\text { 1970, 'Ennerdale, } \\
\text { Seychelles }\end{array}$ & 20,000 tons (Fuel) & & Nelson-Smith (1972) \\
\hline $\begin{array}{l}1970, \text { pipeline } \\
\text { broken, Tarut Bay, } \\
\text { Saudi Arabia }\end{array}$ & $\begin{array}{l}100,000 \text { barrels } \\
\text { (Arabian light crude) }\end{array}$ & $\begin{array}{l}\text { Mortality suffered mainly by crabs, bivalves, } \\
\text { gastropods and numerous fishes. Mangrove trees } \\
\text { less affected. No detrimental effects on corals and } \\
\text { associated fauna. Subsequent recovery of all } \\
\text { habitats good }\end{array}$ & Spooner $(1970)$ \\
\hline $\begin{array}{l}\text { 1970, 'Oceanic } \\
\text { Grandeur', Torres } \\
\text { Strait, N. Great } \\
\text { Barrier Reef, } \\
\text { Australia }\end{array}$ & 1100 tons crude & $\begin{array}{l}\text { Heavy mortalities of pearl oysters near Thursday } \\
\text { Is., Torres Strait }\end{array}$ & S. I. Event No. $24-70$ \\
\hline $\begin{array}{l}1970, \text { Unknown } \\
\text { tanker, near } \\
\text { Pennekamp coral } \\
\text { reef, Florida Keys, } \\
\text { USA }\end{array}$ & $\begin{array}{l}\text { Unknown. Slick } 75 \\
\text { miles long, } 0.5 \text { mile } \\
\text { wide }\end{array}$ & $\begin{array}{l}\text { No oil came ashore. No apparent effects on wild } \\
\text { life }\end{array}$ & S. I. Event No. $106-70$ \\
\hline
\end{tabular}


Table 1. Continued

\begin{tabular}{|c|c|c|c|}
\hline $\begin{array}{l}\text { Time, tanker } \\
\text { and site }\end{array}$ & $\begin{array}{l}\text { Amount and type } \\
\text { of oil spilt }\end{array}$ & Reported effects & Reference \\
\hline $\begin{array}{l}\text { 1971, 'MV Solar } \\
\text { Trader', West. Fayu, } \\
\text { Caroline Is. }\end{array}$ & $\begin{array}{l}520 \text { tons (Fuel and } \\
\text { lubricating) }\end{array}$ & $\begin{array}{l}\text { Numerous dead lobsters and clams. Survey made } 8 \\
\text { months after spill indicated large algal growth on } \\
\text { corals in the area }\end{array}$ & S. I. Event No. 1-72 \\
\hline $\begin{array}{l}\text { 1974, 'Sygna', } \\
\text { Stockton Bight, East } \\
\text { coast of Australia }\end{array}$ & 400 tons (Heavy fuel) & $\begin{array}{l}13 \mathrm{~km} \text { of beaches affected. No damage to marine } \\
\text { life reported }\end{array}$ & Hughes (1974) \\
\hline $\begin{array}{l}\text { 1975. 'MV } \\
\text { Lindenbank' } \\
\text { Fanning Atoll, } \\
\text { Pacific Ocean }\end{array}$ & $\begin{array}{l}10,000 \text { tons copra, } \\
\text { palm oil, coconut oil, } \\
\text { cocoa beans }\end{array}$ & $\begin{array}{l}\text { Fishes, crustaceans and molluscs killed. Extensive } \\
\text { growth of Enteremorpha and Ulva. Complete } \\
\text { recovery of original coralline algal community } \\
\text { after } 11 \text { monts }\end{array}$ & $\begin{array}{l}\text { Russell and Carlson } \\
\text { (1978) }\end{array}$ \\
\hline $\begin{array}{l}\text { 1969-1979, two oil } \\
\text { terminals, Eilat, Red } \\
\text { Sea, Israel }\end{array}$ & $\begin{array}{l}\text { Many small-scale oil } \\
\text { spills. Various } \\
\text { tankers (Iranian } \\
\text { crude-oil) }\end{array}$ & $\begin{array}{l}\text { Decrease in coral and fish diversity } \\
\text { Lack of colonization by hermatypic corals in reef } \\
\text { areas chronically polluted by oil } \\
\text { Damage to the reproductive system of corals }\end{array}$ & $\begin{array}{l}\text { Fishelson }(1973,1977) \\
\text { Loya (1975, 1976a) } \\
\text { Rinkevich and Loya } \\
(1977,1979 \text { a) } \\
\text { Loya and Rinkevich } \\
(1979)\end{array}$ \\
\hline
\end{tabular}

other reef organisms, as well as on the reef flora. Where relevant, effects of oil pollution on other marine organisms are also considered.

\section{FIELD AND LABORATORY REPORTS - GENERAL}

The many varying physical, chemical and biological factors that influence spilled oil tend to make each incident a unique ecological problem. The complex of interacting factors which determine the nature and extent of the biological consequences of such spillage include: the type of oil, oil dosage, physical environmental factors, prevailing weather conditions, nature of the biota, seasonal factors, prior exposure of the area to oil, presence of other pollutants and type of remedial action (Straughan, 1972).

Published field reports following oil spills on the impact of oil on reef organisms are presented in Table 1 and were summarized by Johannes (1975). Most of these field studies report either no damaging effects or the extreme opposite: mass mortality or severe reduction in viability. Physiological, behavioural or morphological long-term effects were rarely reported.

Shinn (1972) suggested that crude oil may represent a minor threat to coral reefs. He based his conclusion on his observations of reef recovery (in oil-polluted areas) following coral mortality due to chilling in the Persian Gulf. With respect to the concern expressed about possible damage to Atlantic reef corals by oil pollution (Lewis, 1971) Shinn stated that it would seem safe to conclude then that crude oil spills do not pose a significant threat to Atlantic reef corals'. However, Shinn's (1972) conclusions were based on a qualitative study, reporting total recovery of the reef killed by the chill (after approximately 6 years), without really measuring the rate of recolonization and without having any data on the coral community structure on this reef before the chill. Similarly, Spooner (1970) reported no damaging effects to reef corals in Tarut Bay, Saudi Arabia, stating that in an area chronically polluted by oil 'there is an area of coral (Acropora sp.) growing healthily with abundant and diverse associated fauna:

While we do not question the facts given in the last two reports, it seems that short-term, incidental or scattered observations may result in misleading conclusions. Furthermore, Stirling (1977) argued that ecological phenomena, such as those caused by oil spills in tropical seas, can be interpreted only when the physiological ecology and population dynamics of the fauna in relation to stability, recruitment and mortality are adequately understood.

Long-term and quantitative studies have now established that oil pollution may cause significant damage to reef corals. Birkeland et al. (1976), for example, found oil-depressed growth rates of corals, and Rinkevich and Loya (1977) reported damage to the reproductive system of corals and an almost complete lack of recolonization of hermatypic corals in reef areas chronically polluted by oil (Loya, 1975; 1976a). The first field evidence that some reef building corals may be seriously damaged if coated with oil when exposed to air at low tide, was provided by Johannes et al. (1975). Twenty-two coral species from Enewetak Atoll were partially exposed to Santa Maria crude oil for $1.5 \mathrm{~h}$. The corals were also exposed to full sunlight for $1 \mathrm{~h}$ and then placed back on the reef. Complete tissue 
breakdown occurred in areas to which oil adhered, in patches of a few mm diameter. No signs of regeneration were observed at the affected areas during 4 weeks of periodical observations, while portions to which oil did not adhere appeared to be healthy.

Johannes (1975) stated that 'when a reef community is destroyed, the ecological conditions that follow cannot be expected to coincide with those which preceded the initial development of the community'. Thus, 'it cannot be granted that the community will ever replace itself'. Loya (1976a) demonstrated the validity of this statement in a long-term field study. The recovery patterns of hermatypic corals following an unpredicted catastrophic low tide were studied on two reef flats near Eilat, Red Sea (Loya, 1975, 1976a). These sites were (1) the nature reserve which is chronically polluted by oil and (2) a control reef which is pollution free. A detailed base-line study, performed in these areas a year prior to the catastrophic low tide, served as basis for comparisons. As a result of the extremely low tide, $90 \%$ of the scleractinian coral communities on the reef flats along the northern Gulf of Eilat were killed. Three years after this event, the clean reef was flourishing with a high diversity of scleractinian corals, while almost no recolonization occurred at the nature reserve. Moreover, the structure of the coral community at the control reef returned to a composition similar to that before the catastrophe, while a drastic change in community structure of corals persisted at the nature reserve. Today, almost 10 years after the mass mortality of the corals, practically no recolonization of coral colonies is evident on the reef flat of the nature reserve (Loya, unpublished).

The report by Birkeland et al. (1976) comprises the only information we have on the effects of oil on growth of corals. They maintain that when mortality does not occur, growth rate is probably the best quantitative and most objective indicator of coral health. The growth-rate study was carried out on a Porites furcata population, as part of a large-scale three-year study on intertidal marine communities near the Galeta Point Laboratory (Panama). Exposure of $P$. furcata to Bunker $\mathrm{C}$ oil for $2.5 \mathrm{~h}$ did not produce detectable effects on the first day following exposure. Nevertheless, mean growth increments of the colonies (studies by Alizarin red staining at the initiation of experiments) were significantly smaller than those of controls after $61 \mathrm{~d}$. The experiments further implied variability in susceptibility of different colonies to oil pollution. While the mean growth of $P$. furcata heads did not differ significantly in clean water, the mean growth of heads subjected to Bunker C oil differed significantly.

Russell and Carlson (1978) described the consequences of edible-oil pollution on Fanning Atoll (about
$1500 \mathrm{~km}$ south of Hawaii). Nearly 10,000 tons of vegetable oils and edible-oil raw materials were spilled on the reef in August 1975 (Table 1). The effects of these oily substances were similar to those occurring after a petroleum oil spill. Fishes, crustaceans and molluscs were killed and an excessive growth of algae, mainly Enteromorpha and Ulva occurred. Complete recovery of the original coralline algal community followed and a climax community became evident 11 months after the original spill.

The only field report to date on the effects of oil films on gas transfer on coral reefs is that of Kinsey (1973). He used a field fencing technique to determine the effects of crude oil films on gas exchange over the coral back reef at Heron Island. Oil films of $0.1 \mathrm{~mm}$ and $0.7 \mathrm{~mm}$ nominal thickness caused no significant interference with $\mathrm{O}_{2}$ and $\mathrm{CO}_{2}$ transfer through the water surface, and respiration of the reef community remained normal. Furthermore, no toxicity effects or abnormal behaviour patterns were observed during 4-5 h of observation.

Dafni (1974) installed coral skeletons (bleached) in two shallow-water areas in Eilat, Red Sea, one of which is chronically polluted by oil and the other pollution free. The coral skeletons served as substrate for settlement of many organisms. After 1 year, the species diversity of organisms colonizing the skeletons was lower in the polluted area than at the clean site. Similar results were reported by Birkeland et al. (1976): over $60 \mathrm{~d}$ a significantly lower biomass of Caribbean fouling organisms had settled on plates coated with marine Diesel oil, compared with control plates.

In another experiment Birkeland et al. (1976) spread marine Diesel and Bunker $\mathrm{C}$ oils on experimental quadrats in the Tetraclita zone at Panama to study succession and recruitment of organisms. Series of collections performed after the oil treatment showed no clear trends in the number and kind of species, or their abundances, in the control and experimental quadrats. Nonetheless, they stress the possibility of subtle changes in certain populations which might manifest themselves only after some time. Thus, Mohammad (1975) found a decrease in survival of a fouling polychaete in the Arabian Gulf, due to an increase in exposure time of experimental areas to chronic oil pollution and Fishelson (1977) reported on extreme reductions in fish populations along the chronically oil-polluted reef flat of Eilat (Red Sea) during 1969-1974

Similar to field reports, laboratory studies vary greatly in their assessments of oil effects on reef corals. Some studies (summarized by Johannes, 1975) indicate no damage to corals by oil floating above them. Lewis' (1971) laboratory experiments which indicated damag- 
ing effects to corals (ruptured tissue, nematocyst discharge, detrimental effects to feeding and tactile response of corals) were criticised by Johannes (1975) as not representing what might occur during an oil spill, since these experiments were carried out in sealed vessels to prevent escape of volatile oil fractions, while in a real oil spill, volatiles would have escaped into the atmosphere. Bak and Elgershuizen (1976) found that patterns of oil sediment rejection by hermatypic corals were identical to the patterns of rejection of clean sediments. They concluded that physical contact with oil-sediment particles appears to be less harmful to corals than the toxic effects of oils.

Although conflicting reports continue to appear in the literature, growing laboratory evidence is accumulating which indicates a detrimental influence of oil to reef corals. Birkeland et al. (1976) exposed hermatypic corals in aquaria to different oils for short periods $(0.5,1.0$ and $30 \mathrm{~min})$ and determined the rate of tissue death. Bunker $\mathrm{C}$ oil had a more damaging effect than marine Diesel oil. The damage to the tested corals varied in different species and did not appear until about 2 weeks after oil exposure.

Peters et al. (1980a) exposed colonies of Manicina areolata to an average of $0.15 \mathrm{ppm}$ No. 2 fuel oil hydrocarbons in a 3 month 'chronic' flow-through bioassay. Gas chromatographic analyses performed on the tissues of these corals showed enhancement of the unresolved peak envelope in the $\mathrm{C}_{14}$ to $\mathrm{C}_{24}$ region. The percentage weight contribution of high boiling polyunsaturated hydrocarbons was reduced in oil-exposed corals, possibly as a result of toxic effects of hydrocarbons on the zooxanthellae. Hydrocarbon enrichment was still evident in contaminated corals after 1 to 2 weeks in clean, flowing sea-water.

Other laboratory experiments indicate detrimental effects of oil on the reproductive system of corals (Loya and Rinkevich, 1979; Rinkevich and Loya, 1979a; Peters et al., 1980b), on behavioural responses (Cohen et al., 1977), and the indirect harmful effects caused by excessive mucous secretion (Mitchell and Chet, 1975; Ducklow, 1977), coagulation necrosis in coenosarc tissue (Peters et al., 1980b) and damage to normal feeding mechanisms (Reimer, 1975a, b) in scleractinian and zoantharian corals. A summary of these reports is given below.

A widely used method to combat oil spills is the dispersion of crude-oil emulcifiers on the polluted areas. The effects of such emulcifiers has been studied in a number of laboratory experiments. It is believed that the toxic effects of one or more components of the spilt oil may be enhanced by crude-oil emulcifiers and thus facilitate their entry into animals, which might be adequately protected from oil alone (Nelson-Smith, 1972). Lewis (1971) reported that oil dispersant
(Corexit) has harmful effects on corals at concentrations of 100 to $500 \mathrm{ppm}$ and that recovery after $24 \mathrm{~h}$ exposure is not complete at these concentrations. According to Elgershuizen and De Kruijf (1976), the mixture of oil and dispersant is more toxic to the stony coral Madracis mirabilis than the two constituents separately. They concluded that in a case of a major oil spill, reefs are more endangered by clean-up with chemical detergents than by the oil itself, and therefore they recommend mechanical removal of the oil.

Eisler and co-workers (Eisler 1973; Eisler et al., 1974; Eisler, 1975a, b; Eisler and Kissil, 1975) studied the effects of crude oils and a chemical oil-dispersant on survival, metabolism and behaviour of representative species of Red Sea coral-reef macrofauna under controlled environmental conditions. The species selected included crustaceans, molluscs, echinoderms and fishes. These authors derived some tentative conclusions concerning the indirect harmful effects of oil and oil dispersant on egg-capsule deposition by the mollusc Drupa granulata. They demonstrated that fecundity of $D$. granulata was a direct function of consumption of the mussel Mytilus variabilis, and that both consumption of $M$. variabilis and fecundity of $D$. granulata significantly decreased when both were exposed to Iranian crude oil $\left(10 \mathrm{ml} \mathrm{l}^{-1}, 168 \mathrm{~h}\right)$. These authors also described abnormal behavioural and physiological patterns in some species. Thus, mussels did not adhere to the walls of test jars by byssus threads and secreted copious quantities of mucus. Rabbit fishes Siganus rivulatus exhibited a lowering in blood hematocrit values and a pronounced enlargement of the liver. In acute toxicity tests it was found that fish and crustaceans were the most sensitive groups assayed, while molluscs were the most resistant.

\section{REPRODUCTION}

There are many gaps in our knowledge of the life history of scleractinian and alcyonarian corals, especially concerning their sexual reproduction. It is not surprising, therefore, that very limited information exists on the effects of oil pollution on coral reproduction. The major source of pertinent information originated from base-line studies on community structure of Red Sea corals at Eilat (Loya, 1972; 1975; 1976a), particularly from experimental field and laboratory studies on the most abundant coral along the Gulf of Eilat, Stylophora pistillata (Loya, 1976b, c; Rinkevich and Loya, 1977; 1979a,b,ci Loya and Rinkevich, 1979).

Loya (1975) suggested that the frequent oil spills around the nature reserve of Eilat resulted in either one or a combination of the following possibilities: (1) damage to the reproductive system of corals; (2) 
decreased viability of coral larvae; (3) changes in some physical properties of the reef flat, which interfere with normal settlement of coral larvae. These possibilities were further investigated by Rinkevich and Loya (1977) on populations of the coral Stylophora pistillata in the field (chronically oil-polluted area vs clean reef) and laboratory. The coral population at the oil-polluted reef showed higher mortality rate of colonies, smaller numer of breeding colonies, a decrease in the average number of ovaria per polyp, smaller number of planulae produced per coral head (fecundity was four times higher in the clean reef) and lower settlement rate of planulae on artificial objects.

An extensive study on the reproductive cycle of Stylophora pistillata (Rinkevich and Loya, 1979b) provided the opportunity to test the effects of oil pollution on reproduction of this species in the laboratory (Rinkevich and Loya, 1979a). The experimental system consisted of four 1500-l capacity tanks with continuous flow of sea water: every week two of these tanks were polluted by Iranian crude oil ( $3 \mathrm{ml} \mathrm{l}^{-1}$ sea water) for $24 \mathrm{~h}$. Large and mature colonies of $S$. pistillata were cut into halves, at the beginning of the reproductive period; one was placed in a polluted tank, the other in a clean tank, thus avoiding expected variation between different colonies. After 2 months, a significant decrease in the number of female gonads per polyp was recorded in $75 \%$ of the polluted halves, compared with the control halves in the clean tanks.

Some evidence of detrimental effects of No. 2 fuel oil on ova of the Caribbean coral Manicina areolata has been provided by Peters et al. (1980b). In static bioassays and flow-through bioassays, some corals either showed degenerating ova or totally lacked normal gonad development. Although no other direct evidence of the detrimental effects of oil pollution on coral reproduction exists, there are indications of detrimental effects on other coral-reef organisms. Eisler et al. (1974) found a decrease in the production of egg cases in the predator gastropod Drupa after exposure to sublethal concentrations of Iranian crude oil. In a field study, Wollodarski (1979) established, a significant decrease of egg production in xanthid crabs living in a chronically oil-polluted reef at Eilat.

Evidence is increasing in the literature of harmful effects of crude oil on reproduction of non-reefal marine invertebrates. Similar effects may be expected in related coral-reef organisms. One possible deleterious effect of oil on reproduction of marine invertebrates is the incorporation of crude-oil derivatives in gonads. Rossi and Anderson (1977) pointed out the propensity of lipid-rich eggs of marine organisms for accumulating and retaining diaromatic hydrocarbons. They exposed males and females of a polychaete worm to sublethal concentrations of No. 2 fuel oil seawater extract for $24 \mathrm{~h}$. Within $1 \mathrm{~h}$ both sexes had incorporated, in equal proportions, most of the diaromatic hydrocarbons eventually accumulated. When returned to clean water, male worms slowly released their accumulated naphthalenes down to undetectable levels. The females, however, retained essentially all of the originally accumulated naphthalenes and only after 3 weeks, when they released their eggs during fertilization, did a decrease of naphthalene content occur. The resulting zygotes and larvae contained most of the naphthalene initially present in parent females. In a subsequent study Rossi and Anderson (1978) found that hatching of the polychaete larvae was inversely related to concentrations of water soluble fractions (WSF) and that fecundity was suppressed in each generation. Similarly, Vaughan (1973) reported accumulation of petroleum hydrocarbons in relatively high proportions in gonads of oysters, following chronic crudeoil exposure. It still remains to be investigated whether such phenomena can lead to the development of malignant tumours, as suggested from studies such as that of Barry and Yevich (1975) who found tumours in the gonadal tissues of clams collected from an oil polluted area.

Mussels which appeared to be unharmed after an oil spill failed to reproduce, while mussels from nearby areas unaffected by the spill were reproducing normally (Blumer et al., 1971). Sublethal concentrations of crude oil decreased amphipod brood numbers, when females were exposed to the oil during the incubation period (Linden, 1976). In planktonic copepods a significant reduction in total number of eggs produced, mean brood size and rate of egg production resulted from short term exposure to high concentrations of water soluble fractions of aromatic heating oil (Berdugo et al., 1977).

Evidence exists for a possible connection between exposure to oil or oil dispersants and adverse effects on success of fertilization in marine invertebrates. Effects of WSF of three crude oils on the sperm and eggs of marine bivalves revealed that fertilization was depressed and spermatozoa in particular were very sensitive. (Renzoni, 1973, 1975). Nicol et al. (1977) found that WSF of No. 2 fuel oil depressed respiration, mobility of sperm and interfered with fertilization in sand dollars. Oil dispersants such as Esso Corexit 9527 reduced the fertilizing capacity of sea-urchin spermatozoa in concentrations down to 0.0003 ppm (Hagström and Lönning, 1977).

\section{LARVAE}

Most of the few works concerning reproduction in hermatypic corals deal with mode and periodicity of 
planulae shedding. However, very little is known of possible effects of oil pollution on this critical stage in the life history of corals.

Loya and Rinkevich (1979) described laboratory experiments where an immediate response of mouth opening was induced by low concentrations of Iranian crude oil in the Red Sea coral Stylophora pistillata. This phenomenon was previously described by Reimer (1975a, b) who indicated damaging effects to the feeding mechanism in corals. In the Red Sea coral, however, crude oil induced abortion: mouth opening was followed by untimely extrusion of numerous larvae. Almost no shedding occurred in the control experiments. If no external distrubance exists, $S$. pistillata sheds its planulae only at night; most larvae are highly developed, with 6 pairs of complete mesenteries (Rinkevich and Loya, 1979a). In the presence of low concentrations of WSF of crude oil the shedding is immediate, during day or night, and most larvae prematurely released (planulae without complete mesenteries or with 2-4 pairs of complete mesenteries). Since planulae extrusion occurs during an oil spill, chances of survival and successful larval settlement are very low. Laboratory experiments on the survivorship of $S$. pistillata planulae exposed to sublethal concentrations of Iranian crude oil $\left(0.01\right.$ to $\left.10.0 \mathrm{ml} \mathrm{l}^{-1}\right)$ showed increasing mortality with increasing concentrations (Rinkevich and Loya, 1977). Furthermore, field documentation (Loya, 1976a) combined with laboratory experiments (Rinkevich and Loya, 1977) revealed that chronic oil pollution inhibits successful settlement of coral planulae. Larval extrusion due to sublethal concentrations of crude oil ( $\left.10 \mathrm{ml}^{-1}\right)$ was also reported in the soft coral Heteroxenia fuscescens, after $72 \mathrm{~h}$ of exposure (Cohen et al., 1977), while only a few larvae were shed by the control colonies.

Chia (1973) exposed 14 species (5 phyla) of pelagic larvae to $0.5 \%$ of No. 2 Diesel oil in sea water and reported that, with the exception of the larvae of an echinoderm which survived for $8 \mathrm{~d}$, they survived for only 3 to $72 \mathrm{~h}$. The common symptoms on the contact with oil and before death for most of these larvae were acute contractions of the gut, asynchronization and sluggish beating of cilia or setae, and occasional violent movements of the body. Chia demonstrated that species specificity, in terms of survival of the larvae in oil-polluted water, may be related to size; larger larvae are expected to survive longer. A similar behavioural response to sublethal concentrations of Iranian crude oil was reported by Loya and Rinkevich (1979) in larvae of the coral Stylophora pistillata.

Larvae and juveniles of some species are apparently as resistant to WSF of crude oils as adults (Swedmark et al., 1971; Renzoni, 1973); in others these stages appear to be very sensitive (Wells, 1972; Moore and
Dwyer, 1974; Wells and Sprague, 1976; Winters et al., 1976; Nicol et al., 1977). Larval stages of marine crustaceans, particularly the early ones, are usually most sensitive to petroleum hydrocarbons (Wells, 1972; Katz, 1973; Wells and Sprague, 1976; Laughlin et al., 1978; Laughlin and Neff, 1979).

In a marine clam, Byrne and Calder (1977) found toxic effects in embryonic and larval stages, as well as slower growth rates in individuals affected by WSF of crude oils. The likelihood of destruction of such larvae in the event of an oil spill was stressed. According to Nicol et al. (1977), WSF of No. 2 fuel oil in concentrations of $4 \%$ or greater prolonged the time of larval development of sand dollars, reduced the number of larvae produced, and resulted in various degrees of larval deformity.

Many fish studies indicate that fish eggs and larval stages are surprisingly resistant to crude oil and water soluble and aromatic fractions of crude oils. Some of this resistance in fish is probably attributable to the presence of enzymes affecting metabolic detoxification (Lee et al., 1972; Neff, 1975; Korn et al., 1976). Other investigators report premature spawning and reduction in survival of fish eggs induced by WSF of crude oil (Struhsaker, 1977) or a decrease in the time interval between fertilization and hatching (Linden et al., 1979). No experimental work has become known to the reviewers regarding oil effects on reproduction, or on survivorship and growth of eggs or juveniles of coralreef fishes.

\section{CHEMORECEPTION, FEEDING RESPONSE AND BEHAVIOUR}

In marine environments, behaviour related to food finding, sexual attraction, homing, predator avoidance and finding of habitats may largely depend on an organism's detection of specific chemical stimuli. One of the dangers of the increasing load of pollutants in the sea is that natural chemically-mediated behaviour, important in the lives of marine organisms, may be disrupted by chronic oil pollution (Blumer et al., 1971).

Detrimental effects to feeding response and tactile stimuli of four Caribbean corals, due to crude oil and oil spill dispersant (Corexit) has been reported by Lewis (1971). Of the four species tested (Porites porites, Madracis asperula, Favia fragum and Agaricia agaricites), $M$. asperula exhibited the greatest ill effects in feeding and tactile responses. Activity decreased markedly upon additions of $50 \mathrm{ppm}$ of crude oil, and at $200 \mathrm{ppm}$ only $5 \%$ of the colonies appeared healthy. Alteration of behavioural responses, such as a marked decrease in the number of tentacles expanded and an increase in extrusion of septal filaments, were also 
observed in the tested corals. All species were more affected by the dispersant than by the crude oil. Lewis (1971) concluded that both pollutants have harmful effects upon corals at concentrations of 100 to $500 \mathrm{ppm}$ and that recovery after $24 \mathrm{~h}$ exposure is not complete at these concentrations

Blumer et al. (1971) warned that crude-oil products may interfere with chemically mediated behaviour by blocking the taste receptors of marine organisms or by mimicking natural stimuli and thus eliciting false responses. Some scleractinian and zoantharian corals have been reported to respond to crude-oil pollution by mouth opening (Reimer, 1975a,b; Loya and Rinkevich, 1979). Normally, contractions and mouth-opening reactions are associated with feeding, as shown from reaction of corals to the amino acid proline and the tripeptid glutathione (Mariscal and Lenhoff, 1968).

Reimer (1975a) described abnormal feeding reactions in four scleractinian corals and the zoanthid coral Palythoa (Reimer, 1975b), elicited by oil floating over the surface water covering the corals (1-4 $\mathrm{ml}$ of marine Diesel or Bunker $\mathrm{C}$ oils $\mathrm{l}^{-1}$ sea water). The treated corals exhibited exaggerated mouth opening which lasted up to $17 \mathrm{~d}$, while control colonies kept their mouths closed throughout $20 \mathrm{~d}$ of observation. Reimer $(1975 a, b)$ suggested some permanent damage to tissues involved in contraction, or perhaps some permanent stimulation of mouth-opening chemoreceptors occurring in the treated colonies. She warned that such interference in chemoreceptive processes by oil may have delayed but longlasting effects on the organisms affected and, indirectly, on the communities in which these organisms participate.

Colonies of the coral Manicina areolata exposed to an average of $0.15 \mathrm{ppm}$ oil hydrocarbons for 3 months in a flow-through bioassay, developed thinning of cell layers of the coenosarc (Peters et al., 1980b). This degeneration was characterized by disruption of normal cell structures (disappearance of ciliated columnar supporting cells, pycnotic nuclei, vacuolation in epidermal cell layer) and a shrunken and granular gastrodermis, which contained reduced numbers of zooxanthellae in various stages of degeneration.

Interference with chemically mediated food attraction due to soluble fractions of oil have been reported in marine snails (Blumer et al., 1973; Jacobson and Boylan, 1973), shore crabs (Shelton, 1971) and lobsters (Atema and Stein, 1974). Kittredge (1973) warned of the destructive effects of water-soluble components on the sensitive neuronal dendrites of the chemoreceptor organs of some invertebrates. Total inhibition of bacterial chemoreception by low concentrations of crude oil have been reported by Mitchell et al., (1972). The bacterial population is not killed, but loses its ability to detect either non-living substrates or living microbial prey. The authors warned that such an inhibition could seriously undermine the capacity of the marine microflora to control self-purification processes in the sea. The latter observations provide another example of serious ecological damage that can occur even if the concentration of pollutants is not high enough to cause immediately demonstrable negative effects on the environment.

Cohen et al., (1977) exposed the pulsatile soft coral Heteroxenia fuscescens to different concentrations of Iranian crude oil in static bioassays $\left(1-30 \mathrm{ml} \mathrm{l}^{-1}\right)$. The initial effect of crude oil (even in the lowest concentration) was a reduction in pulsation rate to less than $50 \%$ of the rate in untreated colonies. The breakdown of synchronized pulsation within a given zooid was even more pronounced than the decrease in pulsation rate. At concentrations of $10 \mathrm{ml} \mathrm{l}^{-1}$ and greater, pulsation stopped almost completely within $72 \mathrm{~h}$. There was a marked difference between untreated and treated colonies in their response to mechanical stimulation. Untreated colonies exhibited immediate synchronised contraction of anthocodia and folding reactions in most of the zooids in response to mechanical stimulation by a glass probe. In polluted colonies, similar stimulation caused an uncoordinated and dispersed folding of tentacles. After a $17-d$ recovery, the pulsation rate of treated colonies was 20-30\% lower and less regular than in control colonies. In large tanks $(1500 \mathrm{l}, 2 \mathrm{~m}$ deep) with a continuous flow of sea water (oil concentration $10 \mathrm{ml} \mathrm{l}^{-1}$ ), a similar reduction in pulsation rate was recorded. The number of colonies exhibiting signs of stress decreased with increased distance from the oil film at the surface.

\section{MUCUS SECRETION AND CORAL REEF FOOD-WEB}

Mucus secretion by reef corals as a protective mechanism in response to external perturbations is well known. Heavy storms, sedimentation, changes in salinity and temperature, and various pollutants are among the obvious causes of extensive mucus secretion by corals. There is no clear evidence of direct harmful effects of crude oil and oil derivatives on corals due to excessive secretion of mucus. Bak and Elgershuizen (1976) studied patterns of oil sediment rejection in 19 hermatypic Caribbean corals and found that oil-sand particles did not induce an obvious increase in mucus secretion compared with the secretion resulting from clean sediment.

Some indication that oil globules may adhere to stony corals has been reported by Marumo and Kamada (1973). Johannes et al. (1972) observed that corals exposed to crude oil varied in their rate of self 
cleaning: in corals with large and fleshy polyps and abundant mucus, such as species of Fungia and Symphyllia, most of the oil disappeared within $1 \mathrm{~d}$ after colony submersion in clean water. Oil adhered with greatest affinity to branching species and was visible on the corals after 4 weeks of observations.

Straughan (1970) hypothesized that corals, like kelp, should suffer little damage after oil spills due to their slimy coats since other organisms which secrete large amounts of mucus (such as certain polychaete species) had been reported to be not affected by oil (George, 1970). However, recent investigations on mucus secretion by corals in response to oil pollution do indicate possible, indirectly detrimental effects to the corals.

Mitchell and Chet (1975) exposed colonies of the brain coral Platygyra to crude oil in aquaria, studying the relationship between mucus production and bacterial growth. Addition of 1000 ppm of crude oil dramatically increased mucus production from 30 (control) to $600 \mu \mathrm{g} 10 \mathrm{ml}^{-1}$ in $24 \mathrm{~h}$. When bacterial growth was prevented by the use of antibiotics, the corals revealed no sign of deterioration, although large quantities of mucus were produced. The authors concluded that crude oil alone fails to kill coral at concentrations of $100 \mathrm{ppm}$, and demonstrated the role of bacteria in coral destruction under stress. They suggested that three groups of microorganisms are responsible for coral death: (1) predatory bacteria attracted chemotactically to the mucus secreted and attacking the coral's tissue; (2) members of the genus Desulfovibrio, which by producing hydrogen sulfide may cause death due to poisoning; (3) species of Beggiatoa causing cell destruction by their filaments.

Ducklow (1977) criticized that Mitchell and Chet (1975) experimented in small aquaria where the rapidly metabolizing corals occupied over $15 \%$ of the tank volume. Even control corals were under great stress in such an environment, thus amplifying pollutant effects. Nevertheless, in experiments on the effects of crude oil the soft coral Heteroxenia fuscescens at Eilat (Red Sea) and on the stony coral Madracis asperula at Bermuda, Ducklow (1977) and Ducklow and Mitchell (1979a) confirmed significant increases in mucus-bacteria populations due to oil pollution and indicated that the diversity of bacterial types was significantly higher in clean mucus than in oil-exposed mucus.

Under normal conditions, mucus loss may be a major pathway of energy loss. Thus, $40 \%$ of the primary production of a species of Acropora is rapidly lost as mucus (Crossland, personal communication). In stressed corals (e.g. due to oil spill) this loss might constitute an enormous energy drain, which could lead to a deterioration in general coral health. For example, Garrett and Ducklow (1975) suggested that naturally occurring diseases in corals, e.g. the black-line disease, may result from stress conditions such as oil pollution.

Since mucus from a variety of stony corals and soft corals has been found to contain energy-rich components, such as wax ester (Benson and Muscatine, 1974). as well as proteins, polysaccharides, lipids, monosaccharides and amino acids (Ducklow and Mitchell, $1979 b$ ), it may be expected that feeding upon coral mucus represents a fundamental energy-transfer process in coral-reef food chains. Mucus may enter the coral reef food web, either as dissolved or particulate organic matter. Particulate mucus has been shown to be consumed by a large variety of coral-reef organisms (Johannes, 1967; Knudsen, 1967; Benson and Muscatine, 1974; Richman et al., 1975; Lewis, 1978). Although there is no conclusive evidence of possible transfer of oil derivatives through the reef food chain, which originates from coral mucus, this remains one possible route, as demonstrated in other organisms, such as clams (Stainken, 1975). Another potential way is through direct feeding on coral tissue, which might contain accumulated hydrocarbons. Thus, some fishes are known to feed on corals (Randall, 1974); the same is true for a large variety of invertebrates (Robertson, 1970).

Incorporation of oil into the coelenteron of the zoanthid Palythoa has been reported by Reimer (1975b) in colonies covered by Bunker C or marine Diesel oils for $30 \mathrm{~min}$. This conclusion was derived through observation of tiny droplets coming out of the polyps' mouths and by the fact that untreated paper ingested by the polyps showed traces of oil when egested. In contrast, Bak and Elgershuizen (1976) found no active ingestion of oil drops by corals. Oil drops introduced into the gastro-vascular cavity were invariably extruded through the stomodaeum. Moreover, no evidence was found of oil absorption to living coral tissues. Accumulation of petroleum hydrocarbons (in the C 11-C 15 and $>$ C 23 ranges) in tissues of the soft coral Heteroxenia fuscescens, exposed to high sublethel levels of Iranian crude oil, were reported by Cohen et al. (1977). The wide range of hydrocarbons found in the tissues of $H$. fuscescens indicated to them that uptake is not limited to water-soluble compounds and, at least within the n-alkane fraction of the oil, non-selective. However, it is not known to what extent pollutant hydrocarbons are retained over long periods.

Information is increasing on accumulation and release of oil derivatives from tissues of a large variety of marine organisms and its passage through the marine food webs. Bivalve molluscs have received particular attention owing to their commercial value and importance in marine food webs (Lee et al., 1972; Stegeman and Teal, 1973; Anderson et al., 1974; Clark 
and Finley, 1975; DiSalvo et al., 1975; Neff et al., 1976). This subject is, however, beyond the scope of the present review.

\section{REEF FLORA}

Very little information exists in the literature concerning oil-pollution effects on algae and higher plants. Most reports are based on qualitative records following oil spills in reef areas; they are often contradictory. Nonetheless, information is now increasing on the effects of oil pollution on algae in temperate and subtropical zones (see reviews by Odum and Johannes, 1975; Zieman, 1975; O'Brien and Dixon, 1976), and much of this is relevant to coral reefs.

Diaz-Piferrer (1962) studied algal communities in Puerto Rico at a site that was accidentally polluted by crude oil a year after his base line observations (Table 1). He found that the marine vegetation was seriously affected, especially plants in intertidal and sublittoral zones. Beds of Thalassia were badly affected, and monthly visits to the polluted area following the spill indicated that this species continued to degenerate. After the spill, the algal community was dominated by one family (Myxophyceae), in contrast to the previous greater evenness in abundance of different types. Mangrove habitats were virtually destroyed in areas where oil accumulated.

A minor effect of an oil spill on mangroves was reported from Tarut Bay, Saudi Arabia (Spooner, 1970). Spooner's observations, 3 months after the spill, showed that some plants lost all their leaves. However, many survived and were bearing flowers and fruits; hence she concluded that the mangrove areas were not affected seriously. In contrast, Rützler and Sterrer (1970) observed that, 2 months after a wreck of an oil tanker in Panama (Table 1), when mangrove trees and shrubs were covered due to high winds by a mixture of oil and sea water to a height of $2 \mathrm{~m}$ above mean tide level, many of these plants were killed, especially young seedlings of Rhizophora. Birkeland et al. (1976) interpreted Rützler and Sterrer's (1970) observations differently, maintaining that the mangrove trees were probably not killed but greatly defoliated. This conclusion was based on the results of experimental spraying of the leaves of Rhizophora with marine Diesel fuel oil; the leaf coverage was reduced and no growth of the trees occurred the following year. Coating the stilt roots with Bunker $C$ oil had a less obvious effect. Birkeland et al. (1976) also studied effects of oil pollution on the surface coverage of algae on settling plates and on intertidal quadrats. They found that the percent coverage of algae on settling plates was significantly higher on plates coated with Bunker $C$ oil than with marine Diesel oil or on control plates. Similarly,
Bunker $\mathrm{C}$ oil was found to enhance the number of algal species in the field quadrats significantly, while the number of species in quadrats sprayed with marine Diesel oil and in the control quadrats did not increase significantly.

Rapid colonization of algae on skeletons of dead corals may be enhanced by oil pollution. Johannes et al. (1972) observed colonization of macroscopic algae on areas of coral skeletons killed by direct contact with crude oil. Dafni (1974) found that in an oil-polluted reef at Eilat (Red Sea) up to $50 \%$ of the surfaces of the coral Stylophora pistillata were covered by the algae Pocokiella variegata, while at a clean station this algal species was not common. This phenomenon was discussed by Fishelson (1973) who suggested that the frequent oil spills combined with phosphate dust (originating from a nearby phosphate loading terminal) seem to be the factors that cause eutrophication in the shallow lagoon waters of the polluted coral area, enhancing the development of algae in place of corals. This process destroyed existing coral colonies, while the occupation of space by algae and the accumulation of sediment between them prevented the renovation by settlement and development of new coral colonies.

Hermatypic corals and other reef animals are known to be in intimate association with dinoflagellate algae, the zooxanthellae. There is a direct linkage between zooxanthellae and corals (growth processes, nutrition, $\mathrm{CO}_{2}$ uptake, etc.). Nonetheless, the effects of oil pollution on zooxanthellae have not yet been studied. Such studies may prove to be of great importance in view of increasingly detrimental crude-oil effects on phytoplankton (Nelson-Smith, 1972). Any detrimental effects of oil pollution on zooxanthellae could result in indirect damage to hermatypic corals. Thus, Pulich et al. (1974) exposed 6 representative marine microalgae to different concentrations of No. 2 fuel oil and found that growth rates of a dinoflagellate, Gymnodinium hallii were most seriously affected. From many laboratory experiments on algae, it is concluded that oils and their components interfere with growth, photosynthesis (reviewed by O'Brien and Dixon, 1976 and Vandermeulen and Ahern, 1976) and synthesis of biologically active compounds, particularly nucleic acids (Davavin et al., 1975).

\section{DISCUSSION AND CONCLUSIONS}

Oil pollution should be considered not only with a view toward short-term but also chronic effects. However, little attention has been given to what happens with the oil once it is out of sight (Murphy, 1971). Blumer et al. (1971) pointed out, as did many other scientists, that although major catastrophes such as the 
wreck of the tanker 'Torrey Canyon' in 1967, or the 'Santa Barbara' leak in 1969, make headlines, the smaller day-to-day spills in coastal waters produce chronic pollution that is much larger in total volume and probably more severe in biological consequences. Long after visible traces of oil disappeared from the sea following the Buzzards Bay oil spill (Blumer et al., 1971), various oil fractions were present in sizeable quantitites in the bottom sediments, down to $13 \mathrm{~m}$ depth (Blumer et al., 1971; Blumer and Sass, 1972).

Community structure and species abundances of marine organisms may change for long periods of time following a single oil spill and perhaps even more so in areas subjected to chronic oil pollution. Thus, 12 years after the 'Tampico Maru' accident, abundances of certain species were still different from previous abundances (Mitchell et al., 1970), and 11 years after a spill caused by the wreck of a tanker in Casco Bay, Maine, residues of hydrocarbons which could be traced to the tanker were still present at the wreck site (Mayo et al., 1974). At the coral nature reserve of Eilat (Red Sea), which is chronically polluted by oil, the community structure of corals has been drastically altered (Loya, 1976a) and has not returned to its 'pre-pollution' structure over the last 10 years.

Many investigators stress the need for base-line biological studies in regions with a high probability of future subjection to pollution, leading to better evaluation and quantification of its long-term effects on animal and plant communities (Mitchell et al., 1970; Birkeland et al., 1976; Stirling, 1977, and others). Often an objective assessment of the consequences of an oil spill is prevented by the absence of data concerning the community structure of affected organisms prior to the spill (Stirling, 1977). However, when such detailed base-line information on community structure and species diversity of corals is available, a firm quantitative basis for comparison and evaluation of alterations in coral communities due to oil pollution is possible (see Loya, 1975; 1976a). The increasing interest in oil exploitation and the expansion and development of oil terminals in the vicinity of coral reefs, extend the need for quantitative base-line studies on coral-reef communities in such areas.

Most accounts of oil spills near coral reefs are qualitative records of personal observations and their value in enabling one to gain knowledge and perspective on the degree of perturbation to reef communities varies. Conclusions from such studies must be considered tentative because of problems involved in differentiating between the effects of numerous environmental factors, each of which could have influenced the results observed (O'Brien and Dixon, 1976). In their survey of marine communities in Panama, Birkeland et al. (1976) stress that 'it is not safe to conclude a lack of harmful effects if the creatures appear to be in good health following an oil spill'. They recommend studying potentially unseen physiological damages to coralreef communities through examination of such variables as coral growth rates and rates of recruitment. We further recommend periodical, long-term and in situ studies of reef populations subjected to chronic oil pollution, whose response to oil might not be immediately obvious. Various features of the life history of species composing such communities should be quantified and, when possible, coupled with controlled experiments in the laboratory. Life-history parameters such as reproduction, growth and survivorship of larvae and adults, settlement and recruitment, should be studied quantitatively, especially for sessile organisms, and many of these aspects should be further investigated in laboratory experiments.

Anderson (1978) stressed the fact that researchers have moved in great strides to improve their analytical input in laboratory studies of oil-pollution effects on marine organisms and seldom do we find a toxicity paper without inclusion of valid analytical information'. However, our review of the literature on experimental laboratory work on coral-reef organisms with respect to oil pollution, reveals that very little has been done and published reports are largely contradictory. In view of our present state of knowledge, we add our voice to the deep concern expressed by coral-reef investigators over possible long-term and harmful effects of oil pollution to reef communities and strongly urge for more research along these lines both in the field and laboratory.

Acknowledgements. This study was made while Y. L. held a Senior Queen Elizabeth Fellowship at the Australian Institute of Marine Science. We are grateful to T. G. Done, R. E. Johannes and D. McB. Williams for thoughtful comments on the manuscript.

\section{LITERATURE CITED}

Anderson, J. W. (1978). Editorial. Mar. environ. Res. 1: 83-85 Anderson, J. W., Neff, J. M., Cox, B. A., Tatem, H. E., Hightower, G. M. (1974). The effects of oil on estuarine animals: toxicity, uptake and depuration respiration. In: Vernberg, F. J., Vernberg, W. B. (eds) Pollution and the physiology of marine organisms. Academic Press, New York, pp. $285-310$

Atema, J., Stein, L. S. (1974). Effects of crude oil on the feeding behavior of the lobster Homarus americanus. Environ. Pollut. 6: 77-86

Bak, R. P. M., Elgershuizen, J. H. W. B. (1976). Patterns of oilsediment rejection in corals. Mar. Biol. 37: 105-113

Barry, M., Yevich, P. P. (1975). The ecological, chemical and histopathological evaluation of an oil spill site. III. Histopathological studies. Mar. Pollut. Bull. 6: 171-173

Benson, A. A., Muscatine, L. (1974). Wax in coral mucus: 
Energy transfer from corals to reef fishes. Limnol. Oceanogr. 19: 810-814

Berdugo, V., Harris, R. P., O'Hara, S. C. (1977), The effect of petroleum hydrocarbons on reproduction of an estuarine planktonic copepod in laboratory cultures. Mar. Pollut. Bull. 8: 138-143

Beynon, L. R. (1971). Dealing with major oil spills at sea. In Hepple, P. (ed.) Water pollution by oil. Institute of Petroleum, London, pp. 187-193

Birkeland, C., Reimer, A. A., Young, J. R. (1976). Survey of marine communities in Panama and experiments with oil, U.S. Environmental Protection Agency, 600/3-76-028

Blumer, M., Sass, J. (1972). The West Falmouth oil spill, II. Chemistry, Woods Hole Oceanogr. Inst. Tech, Rep. 19-72

Blumer, M., Hunt, J. M., Atema, J., Stein, D. (1973). Interaction between marine organisms and oil pollution, U.S. Environmental Protection Agency, R3-73-042

Blumer, M., Sanders, H. L., Grassle, F. J., Hampson, G. R. (1971). A small oil spill. Environment 13: 3-12

Byrne, C. J., CaIder, J. A. (1977). Effects of the water soluble fractions of crude, refined and waste oils on the embryonic and larval stages of the quahog clam Mercenaria sp. Mar. Biol. 40: 225-231

Cerame-Vivas, M. T. (1968). The wreck of the Ocean Eagle. Sea Front. 15: 222-231

Chia, Fu-S. (1973). Killing of marine larvae by Diesel oil. Mar. Pollut. Bull. 4: 29-30

Clark, R. C., Finley, J. S. (1975). Uptake and loss of petroleum hydrocarbons by the mussel Mytilus edulis in laboratory experiments. Fish. Bull. U.S. 73: 508-515

Cohen, Y., Nissenbaum, A., Eisler, R. (1977). Effects of Iranian crude oil on the Red Sea Octocoral Heteroxenia fuscescens. Environ. Pollut. 12: 173-185

Dafni, J. (1974). Animal communities on dead corals under pollution conditions at Eilat, Red Sea. (Hebrew; Engl. summary.) M.Sc, thesis, Tel Aviv University, Israel

Davavin, I. A., Mironov, O. G., Tsimbal, I. M. (1975). Influence of oil on nucleic acids of algae. Mar. Pollut. Bull. 6: 13-15

Dennis, J. V. (1959). Oil pollution survey of the U.S. Atlantic coast. American Petroleum Institute, Washington

Diaz-Piferrer, M. (1962). The effect of an oil spill on the shore of Guanica, Puerto Rico. Ass. Island Mar. Labs., 4th Meet. Curacao, Netherland Antilles, pp. 12-13

DiSalvo, L. H., Guard, H. E., Hunter, L. (1975). Tissue hydrocarbon burden of mussels as potential monitor of environmental hydrocarbons insult. Envir. Sci. Technol. 9: 247-251

Ducklow, H. W. (1977). Influence of sublethal pollutant concentrations on the microbial ecology of living corals. Ph.D. thesis, Harvard University, Cambridge, Massachusetts

Ducklow, H. W., Mitchell, R. (1979a). Bacterial populations and adaptations in the mucus layers on living corals. Limnol. Oceanogr. 24: 715-725

Ducklow, H. W., Mitchell, R. (1979b). Composition of mucus released by coral reef coelenterates. Limnol. Oceanogr. 24: 706-714

Eisler, R. (1973). Latent effects of Iranian crude oil and a chemical oil dispersant on Red Sea molluscs. Israel J Zool. 22: 97-105

Eisler, R. (1975a). Acute toxicities of crude oils and oil dispersant mixtures to Red Sea fishes and invertebrates. Israel J Zool. 24: 16-27

Eisler, R. (1975b). Toxic, sublethal and latent effects of petroleum on Red Sea macrofauna. In: Proceedings of the conference on prevention and control of oil pollution. American Petroleum Institute, Washington. D.C. pp. $535 \sim 540$
Eisler, R., Kissil, G. W. (1975). Toxicities of crude oils and oildispersant mixtures to juvenile rabbitfish, Siganus rivulatus Trans. Am. Fish. Soc. 104: 571-578

Eisler, R., Kissil, G. W., Cohen, Y. (1974). Recent studies on biological effects of crude oils and oil-dispersant mixtures to Red Sea macrofauna. In: Verner, S. (ed.) Proceedings of seminar on methodology for monitoring the marine environment. U.S. Environmental Protection Agency, 600/474-004, pp. 156-179

Elgershuizen, J. H. B. W., De Kruijf, H. A. M. (1976). Toxicity of crude oils and a dispersant to the stony coral Madracis mirabilis. Mar. Pollut. Bull. 7: 22-25

Fishelson, L. (1973). Ecology of coral reefs in the Gulf of Aqaba (Red Sea) influenced by pollution. Oecologia (Berl.) 12: 55-67

Fishelson, L. (1977) Stability and instability of marine ecosystems, illustrated by examples from the Red Sea. Helgoländer wiss. Meeresunters. 30: 18-29

Garrett, P., Ducklow, H. (1975), Coral diseases in Bermuda. Nature, Lond. 253: 349-350

George, J. D. (1970). Sublethal effects on living organisms. Mar. Pollut. Bull. 1: 107-109

Gooding, R. M. (1971). Oil pollution on Wake Island from the tanker R. C. Stoner. U. S. Department Commerce, Nat. Mar. Fish. Service, Spec. scient. Rep. 636

Grant, E. M. (1970). Notes on an experiment upon the effect of crude oil on live corals. Fish. Notes Dept. Primary Ind., Brisbane 1: 1-13

Hagström, B. E., Lönning, S. (1977). The effects of Esso Corexit 9527 on the fertilizing capacity of spermatozoa. Mar. Pollut. Bull. 8: 136-138

Horler, K. M. (1974). The oil exploration industry's role in the royal commissions into oil drilling on the Great Barrier Reef. In: Cameron, A. M. et al. (eds) Proceedings of the second international symposium on coral reefs, Vol. 2. Great Barrier Reef Commission, Brisbane, Australia, pp. 703-714

Hughes, D. (1974). Sygna slick. Mar. Pollut. Bull. 5: 99

Jacobson, S. M. Boylan, D. B. (1973). Effect of seawater soluble fraction of kerosene on chemotaxis in a marine snail, Nassarius obsoletus. Nature, Lond. 241: 213-215

Johannes, R. E. (1967). Ecology of organic aggregates in the vicinity of a coral reef. Limnol. Oceanogr. 12: 189-195

Johannes, R. E. (1975). Pollution and degradation of coral reef communities. In: Ferguson Wood, E. J., Johannes, R. E. (eds) Tropical marine pollution. Elsevier, Amsterdam, pp. 13-51

Johannes, R. E., Maragos, J., Coles, S. L. (1972). Oil damages corals exposed to air. Mar. Pollut. Bull. 3: 29-30

Katz, L. M. (1973). The effects of water soluble fractions of crude oil on larvae of the decapod crustacean Neopanope texana (Sayi). Environ. Pollut. 5: 199-204

Kinne, O. (ed.) (in press). Marine ecology, Vol. V, Ocean management, Wiley, Chichester

Kinsey, D. W (1973). Small scale experiments to determine the effects of crude oil films on gas exchange over the coral back-reef at Heron Island. Environ. Pollut. 4: $167-182$

Kittredge, J. S. (1973). The effects of crude-oil pollution on the behavior of marine invertebrates. Goov. Rep. Announce. 73: 78

Knudsen, J. W. (1967). Trapezia and Tetralia (Decapoda, Brachyura, Xanthidae) as obligate ectoparasites of Pocilloporid and Acroporid corals. Pacif. Sci. 21: 51-57

Korn, S., Hirsch, N., Struhsaker, J. W. (1976). Uptake, distribution and depuration of $\mathrm{C}^{14}$-benzene in northern anchovy Engraulis mordax, and striped bass, Morone sax- 
atilis. Fish. Bull. U.S. 74: 545-551

Laughlin, R. B., Neff, J. M. (1979). Interactive effects of salinity, temperature and polycyclic aromatic hydrocarbons on the survival and development rate of larvae of the mud crab Rhithropanopeus harrisii. Mar. Biol. 53: 281-291

Laughlin, R. B., Young, L. G. L., Neff, J. M. (1978). A longterm study of the effects of water-soluble fractions of No. 2 fuel oil on the survival, development rate and growth of the mud crab Rhithropanopeus harrisii. Mar. Biol. 47: $87-95$

Lee, R. F., Sauerheber, R., Dobbs, G. H. (1972). Uptake metabolism and discharge of polycyclic aromatic hydrocarbons by marine fish. Mar. Biol. 17: 201-208

Lewis, J. B. (1971). The effect of crude oil and an oil spill dispersant on reef corals. Mar. Pollut. Bull. 2: 59-62

Lewis, J B. (1978). Feeding mechanisms in black corals (Antipatharia). J. Zool. 186: 393-396

Linden, O. (1976). Effects of oil on the reproduction of the amphipod Gammarus oceanicus. Ambio 5: 36-37

Linden, O., Sharp, J. R., Laughlin, R., Neff, J. M. (1979). Interactive effects of salinity, temperature and chronic exposure to oil on the survival and development rate of embryos of the estuarine killifish Fundulus heteroclitus. Mar. Biol. 51: 101-109

Loya, Y. (1972). Community structure and species diversity of hermatypic corals at Eilat, Red Sea. Mar. Biol. 13: 100-123

Loya, Y. (1975). Possible effects of water pollution on the community structure of Red Sea corals. Mar. Biol. 29: $177-185$

Loya, Y. (1976a). Recolonization of Red Sea corals affected by natural catastrophes and man-made perturbations. Ecology 57: 278-289

Loya, Y. (1976b). The Red Sea coral Stylophora pistillata is an r strategist. Nature, Lond. 259: 478-480

Loya, Y. (1976c). Settlement, mortality and recruitment of a Red Sea scleractinian coral population. In: Mackie, G. O. (ed.) Coelenterate ecology and behavior, Plenum Publ. Co., New York, pp. 89-100

Loya, Y., Rinkevich, B. (1979). Abortion effect in corals induced by oil pollution. Mar. Ecol. Prog. Ser. 1: 77-80

Mariscal, R. N., Lenhoff, H. M. (1968). The chemical control of feeding behavior in Cyphastrea ocellina and in some other Hawalun fmulh I wp Biol. 49: 689-699

Marumo, R., Kamada, K. (1973). Oil globules and the't attached urganisms in the k'ast China Sea and the Kuroshio area. J. oceanog. Soc. Japan 29: 155-158

Mayo, D. W., Donovan, D. J., Jiang, L., Dow, R. L., Hurst, J. W. (1974). Long-term weathering characteristics of Iranian crude oil: The wreck of the 'Northern Gulf'. In: Marine pollution monitoring (petroleum). Proceedings of a symposium workshop. U.S. Dept Commerce, National Bureau of Standards Spec. Publ. 409, pp. 201-208

Mitchell, C. T., Anderson, E. K., Jones, L. G., North, W. J. (1970). What oil does to ecology. Wat Pollut. Control Fed. 42: 812-818

Mitchell, R., Chet, I. (1975). Bacterial attack of corals in polluted sea water. Micr. Ecol. 2: 227-233

Mitchell, R., Fogel, S., Chet, I. (1972). Bacterial chemoreception: An important ecological phenomenon inhibited by hydrocarbons. Wat. Res. 6: 1137-1140

Mohammad, M. B. M. (1975). Effect of chronic oil pollution on a polychaete. Mar. Pollut. Bull. 5: 21-24

Moore, S. F., Dwyer, R. L. (1974). Effects of oil on marine organisms: a critical assessment of published data. Wat. Res. 8: 819-827

Murphy, T. A. (1971). Environmental effects of oil pollution. J. sanit. Engng Div. Am. Soc. civ. Engrs 97: 361-371
Neff, J. M. (1975). Accumulation and release of petroleum derived aromatic hydrocarbons by marine animals. In: Chemistry, occurrence and measurement of polynuclear aromatic hydrocarbons. American Chemical Society, Petroleum Division, pp 839-849

Neff, J. M., Cox, B. A., Dixit, D., Anderson, J. W (1976). Accumulation and release of petroleum-derived aromatic hydrocarbons by four species of marine animals. Mar. Biol. 38: 279-289

Nelson-Smith, A. (1972). Oil pollution and marine ecology, Plenum Press, New York

Nicol., J. A. C., Donahue, W. H., Wang, R. T., Winters, K. (1977). Chemical composition and effects of water extracts of petroleum on eggs of the sand dollar Melitta quinquiesperforata. Mar. Biol. 40: 309-316

O'Brien, P. Y., Dixon, P. S. (1976). The effects of oils and oil components on algae: a review. Br. Phycol. J. 11: 115--142

Odum, W. E., Johannes, R. E. (1975). The response of mangroves to man induced environmental stress. In: Ferguson Wood, E. J., Johannes, R. E. (eds) Tropical marine pollution. Elsevier, Amsterdam, pp. 52-62

Peters, E. C., Meyers, P. A., Blake. N. J. (1980a). Exposure of the coral Manicina areolata to No. 2 fuel oil. I. Uptake and depuration. Mar. Ecol. Prog. Ser.; in press

Peters, E. C., Blake, N. J., Yevich, P. P. (1980b). Exposure of the coral Manicina areolata to No. 2 fuel oil. II. Behavior and histopathology. Mar. Ecol. Prog. Ser.; in press

Pulich, W. M., Winters, K., Van Baalen, C. (1974). The effects of a No. 2 fuel oil and two crude oils on the growth and photosynthesis of microalgae. Mar Biol. 28: 87-94

Randall, R. H. (1974): The effect of fishes on coral reefs. In: Cameron, A. M. et al. (eds) Proceedings of the second international coral reefs symposium. Vol. 1. Great Berrier Reef Commission, Brisbane, Australia, pp. 159-166

Reimer, A. A. (1975a). Effects of crude oil on corals. Mar. Pollut. Bull. 6: 39-43

Reimer, A. A. (1975b). Effects of crude oil on the feeding behavior of the Zoanthid Palythoa variabilis. Environ. Physiol. Biochem 5: 258-266

Renzoni, A. (1973). Influence of crude oil derivatives and dispersants on larvae. Mar. Pollut. Bull. 4: 9-13

Renzoni, A. (1975). Toxicity of three oils to bivalve gametes and larvae. Mar. Pollut. Bull. 6: 125-128

Richman, S., Loya, Y., Slobodkin, L. B. (1975). The rate of mucus production by corals and its assimilation by the coral reef copepod Acartia negligens. Limnol. Oceanogr. 20: 918-923

Rinkevich, B., Loya, Y. (1977). Harmful effects of chronic oil pollution on a Red Sea coral population. In: Taylor, D. L. (ed.) Proceedings third international coral reef symposium. II. Geology. University of Miami, Miami, pp. $585-591$

Rinkevich, B., Loya, Y. (1979a). Laboratory experiments on the effects of crude oil on the Red Sea coral Stylophora pistillata. Mar. Pollut. Bull. 10: 328--330

Rinkevich, B., Loya, Y. (1979b). The reproduction of the Red Sea coral Stylophora pistillata. I. Gonads and planulae. Mar. Ecol. Prog. Ser.1: 133-144

Rinkevich, B., Loya, Y. (1979c). The reproduction of the Red Sea coral Stylophora pistillata. II. Synchronization in breeding and seasonality of planulae shedding. Mar. Ecol. Prog. Ser. 1: 145-152

Robertson, R. (1970). Review of the predators and parasites of stony corals with special reference to symbiotic prosobranch gastropods. Pacif. Sci. 24: 43-54

Rossi, S. S., Anderson, J. W. (1977). Accumulation and release of fuel-oil-derived diaromatic hydrocarbons by the 
polychaete Neanthes arenaceodentata. Mar. Biol. 39: $51-55$

Rossi, S. S., Anderson, J. W. (1978). Effects of No. 2 fuel oil water-soluble-fractions on growth and reproduction in Neanthes arenaceodentata. (Polychaeta: Annelidae). Water Air \& Soil Pollut. 9: 155-170

Russell, D. J., Carlson, B. A. (1978). Edible-oil pollution on Fanning island. Pacif. Sci. 32: 1-15

Rützler, K., Sterrer, W. (1970). Oil pollution. Damage observed in tropical communities along the Atlantic seaboard of Panama. Bioscience 20: 222-224

Shelton, R. G. J. (1971). Oil pollution and commercial fisheries in Britain. In: Hepple, P. (ed.) Water pollution by oil. The Institute of Petroleum, London, pp. 377-379

Shinn, E. A. (1972). Coral reef recovery in Florida and in the Persian Gulf. Envir. Conser. Dept. Shell Oil Comp., Houston, Texas

S.I.: Smithsonian Institution, Center for short-lived phenomena.

Spooner, M. (1970). Oil spill in Tarut Bay, Saudi Arabia. Mar. Pollut. Bull. 1: 166-167

Spooner, M. F., Spooner, G. M. (1968). The problem of oil spills at sea, illustrated by the stranding of the General Colocotronis on Eleuthera, Bahamas, March 7th, 1968. Mar. Biol. Ass. U.K., Plymouth

Stainken, D. M. (1975). Preliminary observations on the mode of accumulation of No. 2 fuel oil by the soft shell clam Mya arenaria L. In: Proceedings of the conference on prevention and control of oil pollution. American Petroleum Institute, Washington, D. C., pp. 463-468

Stegeman, J. J., Teal, J. M. (1973). Accumulation release and retention of pretoleum hydrocarbons by the oyster Crasostrea virginica. Mar. Biol. 22: $37-44$

Stirling, H. P. (1977). Effects of a spill of marine Diesel oil on the rocky shore fauna of Lamma island, Hong Kong. Environ. Pollut. 12: 93-117

Straughan, D. (1970). Redressing the balance on the reef. Mar
Pollut. Bull. 1: $86-87$

Straughan, D. (1972). Factors causing environmental changes after an oil spill. J. Petrol. Technol. 24: 250-254

Struhsaker, J. W. (1977). Effects of benzene (a toxic component of petroleum) on spawning Pacific herring, Clupea harengus Pallasi. Fish. Bull. U.S. 75: 43-49

Swedmark, M., Braaton, B., Emanuelsson, E., Granmo, A (1971). Biological effects of surface active agents on marine animals. Mar. Biol. 9: 183-201

U.S. Coast Guard (1959). Efforts to reduce oil pollution. Proc. Merchant Mar. Coun. 16: 199-203

U.S. Coast Guard (1969). Sunken tanker project report, Washington

Vandermeulen, J. H., Ahern, T. P. (1976). Effect of petroleum hydrocarbons on algal physiology: review and progress report. In: Lockwood, A. P. M. (ed.) Effects of pollutants on aquatic organisms. Cambridge University Press, Cambridge, pp. 107-125

Vaughan, B. E. (ed.) (1973). Effect of oil and chemically dispersed oil on selected marine biota. - A lab study. American Petroleum Institute Publ. 4191

Wells, P. G. (1972). Influence of Venezuelan crude oil on lobster larvae. Mar. Pollut. Bull. 3: 105-106

Wells, P. G., Sprague, J. B. (1976). Effects of crude oil on American lobster (Homarus americanus) larvae in the laboratory. J. Fish. Res. Bd Can., 33: 1604-1614

Winters, K., O'Donnell, K., Batterton, J. C., Van Baalen, C (1976). Water soluble components of four fuel oils: Chemical characterization and effects on growth of microalgae. Mar. Biol. 36: 269-276

Wollodarski, Z. (1979). Population dynamics of the crab Trapezia on the coral Stylophora pistillata. (Hebrew; Engl. summary.) M.Sc. thesis, Tel Aviv University, Israel

Zieman, J. C. (1975). Tropical sea grass ecosystems and pollution. In: Ferguson Wood, E. J., Johannes, R. E. (eds) Tropical marine pollution, Elsevier Sci. Publ. Comp. Amsterdam, pp. 63

Tropic and authors of this review were suggested by Professor J. Bunt; the review was accepted for printing on May 7,1980 